\title{
Overt-correction vs. Recasts and Grammar Performance of Iranian Male Learners of English
}

\author{
Seyyed Reza Mousavi Moghaddam \\ English language Department, Abadeh Branch, Islamic Azad University, Abadeh, Iran \\ Fatemeh Behjat \\ English language Department, Abadeh Branch, Islamic Azad University, Abadeh, Iran
}

\begin{abstract}
Although a large body of research examined the effectiveness of certain types of error treatment methods, there has been little research done to investigate the efficacy of various kinds of corrective feedback on EFL students' grammar knowledge through eliciting repeated performances. The main purpose of the study was to find out whether recasts helped the Iranian EFL students at intermediate level improve their grammar knowledge better than overt correction. In addition, two methods of recast, declarative and interrogative, were under investigation to figure out which method of recast Iranian EFL learners at intermediate level preferred to be used by the instructor. To this end, fifty male EFL students studying at the intermediate level took part in this study at the Iran Language Institute, Yazd branch, Iran. They were divided into two groups, overt correction and recast. A pre-test was administered before the consecutive process of corrective feedback provision started, and a post-test was given at the end. The participants in both groups enjoyed the same tests, however, the treatment was different. While in one group, the errors were corrected overtly, for the recast group, they were corrected implicitly. The results indicated that both overt correction and recast groups improved in their grammar performances. Between-groups comparison revealed that there was not a significant difference between the learners' grammar performance in overt correction and recast groups. A careful consideration of percentages of declarative and interrogative recasts showed a clear preference for interrogative recasts by the group receiving recasts in their class.
\end{abstract}

Index Terms - corrective feedback, declarative recasts, grammar knowledge, interrogative recasts, overt correction, recasts

\section{INTRODUCTION}

Error correction of both oral and written mistakes occupies a prominent place in English Language Teaching (ELT) literature, and continues to be a divisive issue. In the past, the consensus was that errors of any kind were a bad thing. While reading aloud in class, the student would have every pronunciation mistake corrected on the spot. In written work, all mistakes would be shown, very seriously put in red ink. Offering an answer in class often risked losing face and sometimes being reprimanded for being lazy if the answer was incorrect. More recently, however, in the English language classroom, there has been a shift in attitude to errors. Errors are regarded as indicators that the learner is experimenting with language, or testing out a new language hypothesis, or progressing, in general.

Error correction is deemed essential in ELT classes, for students regard correction as a source of improvement (Chaudron, 1988, as cited in Celce-Murcia, 2001), but teachers take a key role in deciding how much to correct, or how to go about it. Teachers can exploit the errors that a learner makes to show him the current state of his English and to determine the content of future practice. In Brown's (2007) words, "corrective feedback includes responses to learners' produced utterances which repair or call attention to their errors" (p. 379). Lyster and Ranta (1997) categorized six corrective feedback types. They include: explicit (overt) correction, metalinguistic clues, recast, repetition, clarification requests, and elicitation.

Considering two different types of feedback, recast and overt correction, the current study aimed at exploring which one would help the Iranian EFL students improve their grammar performance. In addition, two types of recasts, i.e. declarative and interrogative, will be examined to see which one students prefer to be used by their grammar teachers in the language classroom.

\section{LITERATURE REVIEW}

From the historical stand point, it is obvious that the provision of corrective feedback is a recurrent practice in the field of education in general, and in language learning and teaching in particular. Generally, it includes providing either formal or informal feedback for learners on their performance by their teacher or peer(s) on different tasks. The most common terms used in the second language acquisition (SLA) field that refer to corrective feedback are negative evidence, negative feedback, and corrective feedback. Owing to possible perplexity arising out of the use of these terms, a concise review of their definitions by some researchers in the field is presented below. 
Dulay, Burt, and Krashen (1982) define feedback as the listener or reader's response provided to the learners' spoken or written production. Chaudron (1986) explains that the concept of correction is "any reaction by the teacher which transforms, refers to, or demands improvement of a student's behavior or utterance" (p. 66). According to Chaudron (1988), corrective feedback denotes different meanings. In his words, the term "treatment of error" refers to "any teacher behavior following an error that minimally attempts to inform the learner of the fact of error" (p. 150). Keh (1990) defines feedback as "input from a reader to a writer with the effect for providing information to the writer for revision" (p. 294).

Schachter (1991) states that, corrective feedback can be typically found in language learning and teaching. She mentions 'negative data' or 'negative evidence' as its counterpart in the linguistic field of acquisition. Long (1996) believes that input can be offered to learners in the form of negative and positive evidence. Negative evidence is defined by Long as supplying the direct or indirect information to the students about what is not appropriate and positive evidence as supplying the appropriate and grammatical models in the target language to the students. This information might be provided in the form of what is called explicit and implicit corrective feedback.

Corrective feedback is defined by Lightbown and Spada (1999) as "any indication to the learners that their use of the target language is incorrect. This includes various responses that the learners receive after making errors. When a language learner says, ('He go to school every day'), corrective feedback can be explicit (for example, 'no, you should say goes, not go') or implicit ('yes he goes to school every day'), and may or may not include metalinguistic information, for example, ('don't forget to make the verb agree with the subject')" (p. 171-2).

In Suzuki's (2005) words, corrective feedback is regarded as a pedagogical means of supplying the learners with modified input, which can cause the learners to produce modified output. Ellis (2009) views corrective feedback as one type of negative feedback. According to him, it is for any form of response a learner's utterance including a linguistic error. The response comprises any indication that an utterance contains errors, provision of the metalinguistic information or the appropriate target form or any combination of them. Corrective feedback research "constitutes an area of inquiry that can connect theory, research and practice" (Sheen, 2010, p.177).

It has been suggested that certain corrective feedback types can assist grammar improvement, thanks to the type of information supplied to the students by corrective feedback and the depth of processing it can develop (Panova \& Lyster, 2002). In Ranta and Lyster's (2007) words, corrective feedback falls into two main categories: prompts and reformulations. Prompts consist of clarification requests, repetition, metalinguistic clues, and elicitation. Reformulations consist of overt correction and recasts.

Overt correction happens when the teacher intervenes by pointing out where and how learners are wrong. It can also entail asking a student to repeat the corrected version of an utterance. A compelling reason and justification for sometimes giving overt correction is simply that many learners expect or want their errors to be corrected in this way. Maybe this is because it reflects the traditional view of what a teacher does. These days, students often complain about not being corrected enough rarely about being corrected too much.

Lyster and Ranta (1997) believe that overt correction unlike recasts, "clearly indicates what the student had said was incorrect" (p. 46). They claim that overt correction is one of the least ambiguous forms of correction; yet, in their study, this technique did not show to be very effective. Kim and Mathes (2001) regard overt correction as providing the correct form overtly which contains specific grammatical information. Learners can refer to this information when their utterances are wrong. Moreover, In Brown's (2007) view, overt/ direct correction occurs when the instructor points out an error and provides the accurate form. In overt correction, there will be an overt indicator that an error has been arisen; by contrast, in implicit correction, there will not be (Yang \& Lyster, 2010). In her paper, Hinkel (2011) stated that overt correction occurs "when the teacher directly corrects the learner and/or provides some kind of metalinguistic explanation of the error" (p. 593). This is illustrated in the following example.

$\mathrm{S}$ (student): Yesterday Joe and Bill (ah) went to (ah) Bill's grandmother and visit their grandmother

$\mathrm{T}$ (teacher): and visit-you need past tense

S: Visited, yes.

(Ellis, Loewen, \& Erlam, 2006)

There are some studies in the literature which support the efficacy of overt correction. Semke (1984) pointed out that implicit methods of corrective feedback are less useful than explicit ones and lead to less achievement; besides, learners do not have a positive view regarding this type of error treatment. Edge (1989) stated that the teacher should provide directly the learners with the correct grammatical structures in writing process where they think that their performance is wrong and the existing errors cause some sort of misunderstanding or ambiguity in their flow of communication. He confirmed that particularly with certain types of error, explicit (overt) corrective feedback is significantly more effective than implicit type.

In the studies by Herron and Tomasello (1988), Tomasello and Herron (1989), Herron (1991), and Ellis, Rosszell, and Takashima (1994), overt correction occurred through so-called garden-path techniques that persuaded students to commit errors while using the target forms. Their errors provoked a response from their teacher. The teacher wrote the inaccurate form on the board, drew a line through it, wrote the proper form, and then stated it out loud before offering a concise explanation. By the same token, Bartram and Walton (1994) found that overt correction is the most commonly 
used type of feedback in communicative activities. Nevertheless, it causes a breakdown in communication and makes the students feel uncomfortable, and reluctant to communicate in the target language.

A body of research, carried out by Leow (1998) and Scott $(1989,1990)$ revealed that overt correction is more fruitful than implicit corrective feedback. Ferris (1999) classified errors into treatable and untreatable errors. By treatable errors, she referred to rule-governed errors such as those in subject-verb agreement, comma, missing articles and verb form errors. She defined untreatable errors as lexical, wrong sentence construction, missing words, unnecessary words and wrong word order errors. She stated that teachers should not provide implicit corrective feedback (such as underlining, abbreviation, etc.) for untreatable errors because these errors have no rules. Thus, overt corrective feedback is suggested for errors which are not rule-governed.

Nassaji and Swain (2000) highlighted the point that "there was a tendency for more direct and explicit prompts to be more useful than less direct implicit prompts". In the same way, Norris and Ortega's (2000) meta-analysis of L2 instructional interventions suggested that the outcome measures utilized by a great number of studies bore out the efficacy of overt correction for the reason that these measures demanded "the application of explicit declarative knowledge under controlled conditions, without much requirement for fluent, spontaneous use of contextualized language" (p. 486).

In the same fashion, Ferris and Roberts (2001) discovered that low proficiency students gained advantage from having their teacher correct their errors. Lack of feedback prevented students from noticing their errors. As a result, students felt a sense of frustration. They suggested that implicit correction enhances the students' reflection and attention to their errors, and in the same way, it gets the students involved in guided learning, which results in long-term retention.

In an empirical study, Ellis, Loewen, and Erlam (2006) investigated learners' use of the English past tense marker ed following exposure to either metalinguistic clues or recasts. The Results revealed that students receiving metalinguistic clues in their group surpassed both the recast and control groups on tests of both oral elicited information and grammaticality judgments L2 knowledge. According to Ellis et al. (2006), "explicit feedback seems more likely to promote cognitive comparison that aids learning" (p. 364). Additionally, it is in line with the findings of Carroll's (2001) study concluding that metalinguistic clues and not recasts appear to promote generalization of the -ed form to new contexts.

In Mackey and Goo's (2007) study, eleven L2 learners of Arabic and their two teachers watched videotaped corrective feedback (CF) episodes from the interactions in their classes. Results showed that, on the whole, the perception of the $\mathrm{CF}$ was just $36 \%$ which was not the teachers' original intention. For instance, CF targeted a morphosyntactic error was quite identified as morphosyntactic CF by the students. Overt correction (either including metalinguistic clues or elicitation) was understood more than implicit CF such as negotiations for meaning and recasts. In her study, Sheen (2007) examined the efficacy of implicit feedback (recasts) and overt correction together with metalinguistic comments on adult ESL learners' acquisition of definite and indefinite articles. The results revealed that overt correction group outperformed the implicit group in learning in both immediate and post-tests. She concluded that overt correction is more helpful than implicit correction in a classroom context.

Regarding the benefits of overt correction, Ortega (2009, p. 75) assumed that "when two or more implementations of negative feedback are compared, the more explicit one leads to larger gains" and continued to declare that this result "is hardly illuminating" since it reflects Norris and Ortega's (2000) meta-analysis results regarding the dominance of overt (explicit) CF types over more implicit ones (see also Spada \& Tomita, 2010). A large number of studies bore a crucial role of explicit written corrective feedback on learners' linguistic errors (Bitchener, 2008; Bitchener \& Knoch, 2009; Sheen, 2010). These studies informed of the short-term efficacy of written corrective feedback.

Recasts are an attempt to imitate the way in which real-life correction happens. Typically, it is the way people in the street or in shops react to learners' errors, and it is generally how parents correct their children. Recasts are an indirect and gentle way of giving feedback, in which the teacher reformulates all or part of an utterance into a correct or more appropriate version of what a learner is trying to say. Recasts are defined as "utterances that rephrase a child's utterance by changing one or more sentence components, subject, verb or object, while still referring to its central meaning" (Long, 1996, p. 434). According to Lyster and Ranta (1997), recasting is "the teacher's reformulation of all or part of a student's utterance, minus the error" (p. 46). In Sheen's (2006) view, a recast is “The teacher's reformulation of all or part of a student's utterance that contains at least one error within the context of a communicative activity in the classroom" (p. 365).

A recast occurs in episodes such as the following examples:

(4) T: When you were in school?

L: Yes, I stand in the first row.

$\mathrm{T}$ : You stood in the first row?

L: Yes, in the first row, and sit, ah, sat the first row.

(Ellis \& Sheen, 2006, p. 576)

In Line 1, a learner's utterance containing an error (Line 2) triggers the recast (Line 3), which reformulates the utterance and corrects the error.

In their study, Loewen and Philp (2006) explained the features of recasts as follows: 
“1) Recasts are generally provided incidentally in the course of focus-on-meaning interaction in response to nontarget-like utterances;

2) Recasts retain the central meaning of the learner's utterance while changing the lexical, morphosyntactic, or phonological form;

3) Recasts provide positive evidence and negative feedback rather than providing overt correction" (p. 537).

A large number of researchers distinguished various types of CF in relation to explicitness, but it has turned out to be highly problematic.

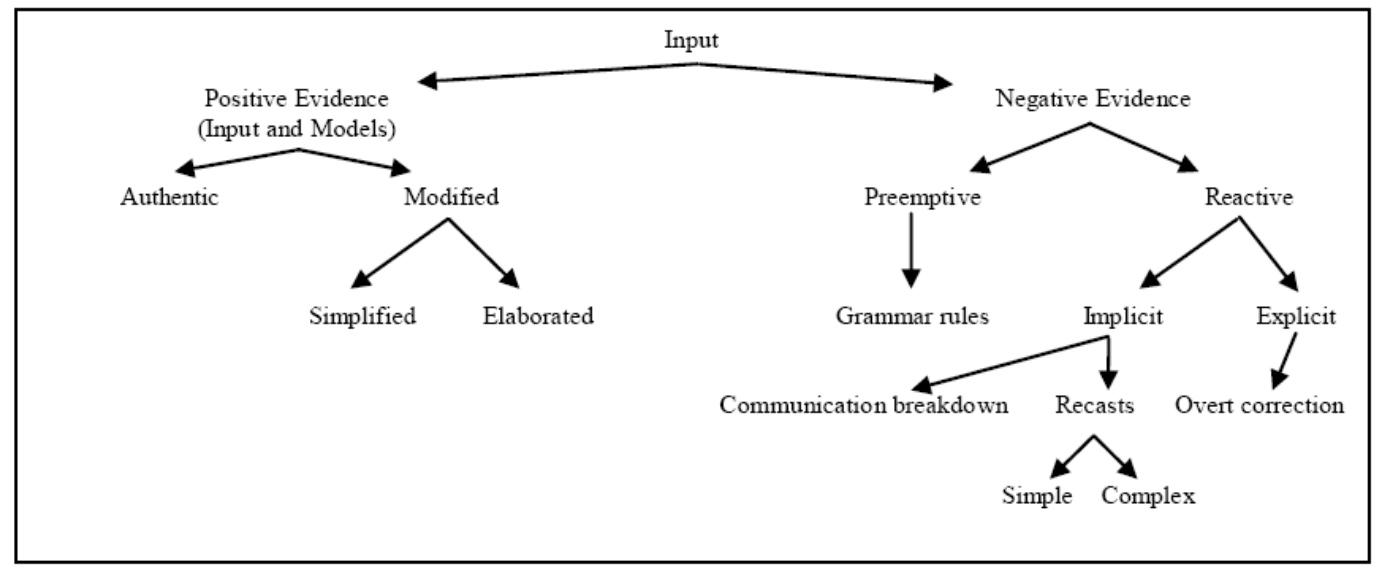

Figure1. From "Focus on Form: Theory, Research and Practice" by M. Long and P. Robinson (1998).

As Figure 1 shows, recasts, for instance, are wildly regarded as implicit (Long, 1996, 2006; Long \& Robinson, 1998), yet research indicates that, recasts can also be quite explicit, depending on learner orientation, instructional setting, and discourse context in addition to formal characteristics such as number of changes, length, and linguistic targets (Nicholas, Lightbown, \& Spada, 2001; Sheen, 2004, 2006; Ellis \& Sheen, 2006; Sato, 2011). Loewen and Philp (2006) admitted that recasts fluctuate from more implicit to more explicit. Farrar (1990, 1992) endorsed the provision of recasts, claiming that they provide positive evidence, i.e. the grammatical forms in the target language, and also negative evidence, i.e. the ungrammatical ones in the target language.

There is also some evidence in the literature which supports the use of recasts in a foreign language context. Long and Robinson (1998) suggested that recasts are highly beneficial to show learners the difference between their interlanguage and target language. Nicholas, Lightbown, and Spada (2001) consider recasts as a corrective feedback type to language learners, that is a review on the usefulness of recasts, coming to the conclusion that "recasts appear to be the most effective in the contexts where it is clear to learners that the recast is a reaction to the accuracy of the form, not the content, of the original utterance" (p. 720). Another example of research done on recasting is Lyster's (2001) investigating specific patterns of a reactive approach to form-focused instruction that could be named corrective feedback. It was found that phonological and grammatical errors had a tendency towards recasts whereas lexical errors attracted more negotiation of form than recasts.

Han (2002) carried out a study to investigate the effect of recasts on tense consistency in L2 output. She designed a pretest, posttest, and a delayed posttest. The participants were randomly divided into a recast group and a non-recast group. The database was composed of written and oral narratives from both groups collected during eleven sessions. The statistical analysis showed that owing to their finely tuned awareness, the recast group outperformed the non-recast group in showing a much greater control of tense consistency in both oral and written tests. Moreover, Mackey and Oliver (2002) found that children are more sensitive to recasts owing to the fact that recasts bear a striking similarity to first language (L1) feedback given by caregivers.

In the same fashion, Leeman (2003) carried out a study with 74 freshmen learners of Spanish employing Spanish noun-adjective agreement at a university. Four groups performed communicative tasks one-on-one with the researcher. They include: negative evidence group, enhanced salience with no feedback group, recast group, and control group. The findings from a posttest and delayed posttest with picture description tasks revealed that only recast group and enhanced salience with no feedback group surpassed the control group on any measure.

Regarding the short-term benefits of recasts, Iwashita (2003) conducted a study with the focus on two grammatical structures in the task-based conversational interactions occurring between adult learners of Japanese and NSs. The statistical analysis showed the short-term effect of recasts compared with other conversational moves.

For the same reason, Ishida (2004) studied the impacts of recasting on the acquisition of Japanese aspectual form -te $\mathrm{i}(\mathrm{ru})$, leading to the significantly increased overall accuracy in connection with the number of recasts which was given throughout the treatment period, and the accuracy rate was sustained. Ellis and sheen (2006) in their research entitled "Reexamining the role of recasts in second language acquisition" argued the probability of overestimation about acquisition usefulness of recasts compared with other corrective feedback types. 
In addition, McDonough (2007) examined the effectiveness of clarification requests and recasts, either of them opened up opportunities for immediate repair, and detected no crucial distinction between clarification requests and recasts, even though these two kinds of CF turned out to be more fruitful than no CF. To take this idea one step further, Perdomo (2008) investigated the efficacy of explicit negative feedback and recasts on the right use of the auxiliary verb "to have", and the use of past participles in the present perfect tense. Thirty-eight students were randomly divided into two groups, namely explicit negative feedback and recast groups. Findings lead support to the efficacy of recasts over explicit negative feedback.

Likewise, Sheen (2008) examined the impacts of language anxiety on the efficacy of recasts, concluding that recasts had a positive effect on low-anxiety learners compared with both high-anxiety learners who received recasts and lowanxiety learners for whom recasts were not provided as a control group. Findings did not show a difference between the high-anxiety learners and the control group. In a recent study, R'ev'esz, Sachs, and Mackey (2011) investigated whether the task design variable \pm visual support had an effect on the amount of students' responses to recasts and the correlation between uptake and L2 development. Fifty four EFL learners from a high school took part in the study in Hungary. The findings of the study indicated that immediate repair following recasts of past progressive forms could be a good predictor of improvement when learners performed less complicated tasks.

Lyster (1998b) classified recasts into two major types: declarative and interrogative recasts. Declarative recast states that something is incorrect in the learners' utterance through statements and the repetition of the same sentence produced by a student. Interrogative recast points out that something is incorrect in the learners' utterance through asking a question directly or restating the sentence as a question. Lyster (1998a) states that "interrogative recasts often serve as conformation checks" (P. 201).

Sheen (2006) stated that students are most likely to repair their errors following declarative recasts. She also pointed out that interrogative recasts did not lead to a high level of repair declaring that "uptake and subsequent repair are more likely when the linguistic focus of recasts is on pronunciation and when the type of change involved substitution because these characteristics are linked with length, word or short phrase, and a single change" (P. 386). In a word, interrogative recasts were not beneficial to repair.

Loewen and Philp (2006) concluded that "stress, declarative intonation, one change, and multiple feedback moves were predictive of successful uptake" (p. 540). They identified that "interrogative intonation, shortened length, and one change were predictive of the accuracy of the test scores" (p. 540). Results of their study revealed that interrogative recasts have the effect of developing learners' accuracy. Additionally, they mentioned that "an interrogative recast is ambiguous as corrective feedback because the learner may interpret it either as corrective or as a request to confirm the intended meaning" (p. 540). On the contrary, in Mackey and Goo's (2007) study, eleven L2 learners of Arabic and their two teachers watched videotaped CF episodes from the interactions in their classes. Results indicated that the perception of the CF was just 36\% which was not the teachers' original intention. Regarding the types of recasts, students identified interrogative recasts more than declarative recasts.

More recently, Erlam and Loewen (2010) distinguished between implicit and explicit recasts depending on the number of moves and the intonation of the CF. The operationalization of a recast may verify the degree of its implicitness or explicitness, for example in Erlam and Loewen (2010), the implicit recasts (interrogative) -- including correction of the error made, with rising intonation -- is in contrast with explicit recast, declarative, which consists of two uninterrupted feedback moves. In the first, the student's error was repeated with rising intonation. In the second, a correction was provided in declarative form (p.886).

Following the literature on the role of feedback in grammar performance of language learners, the following research questions were posed:

1. Does recast help Iranian EFL learners at intermediate level improve their grammar knowledge better than overtcorrection?

2. Which methods of recast, declarative or interrogative, do Iranian EFL learners at intermediate level prefer their instructors use as a feedback to their grammar performances?

Based on the above-mentioned research questions, two null hypotheses were made.

\section{METHOD}

\section{A. Participants}

The participants of this study were 50 male EFL students studying at the Iran Language Institute, Yazd branch, Iran. The students were at the intermediate level in the 15-25 age range. All participants had taken the placement test required for being accepted to study English in the institute; therefore, they were assumed to enjoy the same language knowledge. They were native speakers of Persian studying English in the foreign language setting.

\section{B. Instruments}

The research instrument used in the study involved a number of 30 multiple-choice questions derived from the book "Progress toward ILI Examinations: Pre 3 Intermediate" (Lotfian, 2009). Prior to the actual test administration, this test was piloted for its reliability, and also content validity; it was examined by two faculty members of Islamic Azad 
University of Abadeh, Iran, who agreed that the test enjoyed a high level of content validity. The piloted test data was entered into a computer and analyzed. The result of the analysis indicated an approximate reliability of 0.71 . In addition, to answer the second research question, a survey was carried out to find the learners' preference for declarative or interrogative recasts.

\section{Procedures}

This study aimed at comparing two different corrective treatments, overt-correction and recast to see which one was more effective for the Iranian learners' grammar improvement by giving consecutive treatments and administering tests. Permission to conduct the research was sought and obtained from the central office in Tehran, Iran. The current study used an experimental method, yielded quantitative data and provided statistical analysis.

To fulfill this aim, a pre-test of grammar was given to the students at the beginning before the process of corrective feedback provision started. The purpose of giving this test was first for homogeneity purposes and then, for later comparison between the performance of students at the end and that of the beginning to see if there was any significant difference in the grammar performances of the two groups receiving recast and over-correction or not. The test which was used both the pre- and post-test consisted of a number of multiple-choice questions. The allotted time to answer the items of the test was nearly 20 minutes. Then, the students were divided into two groups of about 30 students. Because of institutional constraints, it was not possible to have a control group to compare with the experimental groups receiving overt-correction and recast as the students' mistakes were supposed to be corrected one way or another in all classes. The test was the same for both groups in which the teacher used overt-correction and recast.

Then the next phase of the study was the treatment. The researcher, who was a teacher at the Iran Language Institute, Yazd branch, Iran, instructed the classes. Both groups received the same instruction. The only difference lay in the process of corrective feedback used during the instruction, overt-correction for one group and recast for another. The difference is illustrated in the following examples which are the actual data collected in the present study.

(1) S (student): I go to the movies yesterday afternoon.

$\mathrm{T}$ (teacher): You went to the movies.

What did you see?

S: 'Scandal'.

In the above-mentioned example, the teacher supplies the correct form (went) without interrupting the flow of speech, thus maintaining a focus on meaning.

(2) S: Several years ago, Masaru Ibuka, the chairman of Sony, remove the recording function and speaker.

$\mathrm{T}$ : No, not remove -- removed. The verb must be in the past tense.

In this example, the teacher directly corrects the learner's erroneous utterance.

As the educational sessions of the Iran Language Institute were held 105 minutes twice a week during an elevenweek period, the process of corrective feedback provision took a total of twenty sessions. At the end of the instruction, the participants took their final test, post-test, which was administered in the last session of the term. Next, the group receiving recast were surveyed to see which method of recast Iranian EFL students at intermediate levels preferred their teachers to use to give feedback to their students, declarative or interrogative.

\section{RESULTS AND DISCUSSION}

In order to compare the participants' performances in the pre- and post-test for both groups, those receiving overt correction and those receiving declarative and interrogative recast, independent samples and paired samples $t$-tests were applied. Paired samples $t$-tests were carried out on the performances of both overt correction and recast groups before and after the instruction separately to find out whether there is a significant difference between the mean scores of the learners' performances in the grammar test constructed to assess their knowledge of English grammar in the pre- and post-test. Then, in order to compare the gain scores of the participants in the overt correction and recast group, an independent sample $t$-test was performed. To answer the second research question, the percentages were obtained to show which type of recast, declarative or interrogative, was preferred by the learners who received recast in their class.

The results of paired sample $t$-tests for overt correction group shows that the mean scores of the group in pre- and post-test were 18.24 and 25.52, respectively (see Table I). This means that the learners improved their grammar performance in post-test.

TABLE I.

PAIRED SAMPLES STATISTICS FOR OVERT CORRECTION GROUP

\begin{tabular}{|r|l|l|l|l|}
\hline & Mean & $\mathrm{N}$ & Std. Deviation & Std. Error Mean \\
\hline Pair 1 pre-test (Overt Correction) & 18.24 & 25 & 2.919 & .584 \\
post-test (Overt Correction) & 22.52 & 25 & 2.584 & .517 \\
\hline
\end{tabular}

In order to see if the observed difference was statistically significant, a paired sample $t$-test was applied. The results are presented in Table II as follows: 
TABLE II.

PAIRED SAMPLES T-TEST FOR OVERT CORRECTION GROUP

\begin{tabular}{|c|c|c|c|c|c|c|c|c|c|}
\hline & & \multicolumn{5}{|c|}{ Paired Differences } & \multirow[b]{3}{*}{$t$} & \multirow[b]{3}{*}{ Df } & \multirow{3}{*}{$\begin{array}{l}\text { Sig. }(2 \\
\text { tailed })\end{array}$} \\
\hline & & \multirow[b]{2}{*}{ Mean } & \multirow{2}{*}{$\begin{array}{l}\text { Std. } \\
\text { Deviation }\end{array}$} & \multirow{2}{*}{$\begin{array}{l}\text { Std. Error } \\
\text { Mean }\end{array}$} & \multicolumn{2}{|c|}{$\begin{array}{l}95 \% \text { Confidence Interval of the } \\
\text { Difference }\end{array}$} & & & \\
\hline & & & & & Lower & Upper & & & \\
\hline Pair 1 & $\begin{array}{l}\text { pre-test (Overt Correction) - post-test } \\
\text { (Overt Correction) }\end{array}$ & -4.280 & 2.807 & .561 & -5.438 & -3.122 & -7.625 & 24 & .000 \\
\hline
\end{tabular}

The results of the paired samples $t$-test for this group presented in Table II indicate that the observed difference between the mean score of pre- and post-test was significant $(\mathrm{t}=-7.625, \mathrm{df}=24, \mathrm{p}=0)$ at the significance level of 0.000 as the observed $t$ exceeds the significance level.

Table II reveals that the participants' scores in post-test in the overt correction group are significantly higher than the scores in pre-test, and this difference can be attributed to the helpful role of the treatment particularly overt correction feedback. Higher scores mean a higher level of learners' awareness of English grammar. Then, a sample paired statistics was used for the recast group (Table III):

TABLE III.

PAIRED SAMPLES STATISTICS FOR RECAST GROUP

\begin{tabular}{|c|c|c|c|c|}
\hline & Mean & $\mathrm{N}$ & Std. Deviation & Std. Error Mean \\
\hline \multirow[t]{2}{*}{ Pair 1 pre-test (Recast) } & 18.96 & 25 & 2.746 & .549 \\
\hline & 23.00 & 25 & 3.227 & .645 \\
\hline
\end{tabular}

The results of the paired samples statistics for the recast group, presented in Table III indicate that the mean scores of the group in pre- and post-test were 18.96 and 23 respectively. This means that they increased their accuracy in post-test. If this difference is statistically significant, one can conclude that they have improved in their grammar performance, and higher accuracy in these tests implies a higher level of their awareness of English grammar.

In order to see whether the difference was significant, a paired sample $t$-test was applied. The results are tabulated as follows:

TABLE IV.

PAIRED SAMPLES T-TEST FOR RECAST GROUP

\begin{tabular}{|c|c|c|c|c|c|c|c|c|}
\hline & \multicolumn{5}{|c|}{ Paired Differences } & \multirow[b]{3}{*}{$\mathrm{t}$} & \multirow[b]{3}{*}{ df } & \multirow[b]{3}{*}{ Sig. (2-tailed) } \\
\hline & \multirow[b]{2}{*}{ Mean } & \multirow[b]{2}{*}{ Std. Deviation } & \multirow{2}{*}{ Std. Error Mean } & \multicolumn{2}{|c|}{$\begin{array}{l}95 \% \text { Confidence Interval of the } \\
\text { Difference }\end{array}$} & & & \\
\hline & & & & Lower & Upper & & & \\
\hline \begin{tabular}{|ll} 
Pair 1 & $\begin{array}{l}\text { pre-test (Recast) - post-test } \\
\text { (Recast) }\end{array}$ \\
\end{tabular} & -4.040 & 2.541 & .508 & -5.089 & -2.991 & -7.950 & 24 & .000 \\
\hline
\end{tabular}

The results of the paired samples $t$-test for this group presented in Table IV indicate that the observed difference between the mean score of the learners in pre- and post-test was significant $(t=-7.950, d f=24, p=0)$ as the significance level is 0.000 and $t$ exceeds the significance level. This means that their scores in post-test are significantly higher than their scores in pre-test and this difference can be attributed to the effective role of recast.

Table $\mathrm{V}$ below indicates the results of group statistics for the grammar gain scores of both recast and overt correction groups. The mean of the participants' gain scores in these groups are 4.04 and 4.28 respectively.

TABLE V.

GROUP STATISTICS FOR RECAST AND OVERT CORRECTION GROUPS

\begin{tabular}{|l|l|l|l|l|}
\hline group & $\mathrm{N}$ & Mean & Std. Deviation & Std. Error Mean \\
\hline Recast & 25 & 4.04 & 2.541 & .508 \\
Overt Correction & 25 & 4.28 & 2.807 & .561 \\
\hline
\end{tabular}

To see if the observed difference is significant or not, an independent sample t-test was performed, the results of which are presented in Table VI.

TABLE VI

INDEPENDENT SAMPLES T-TEST FOR OVERT CORRECTION AND RECAST GROUPS

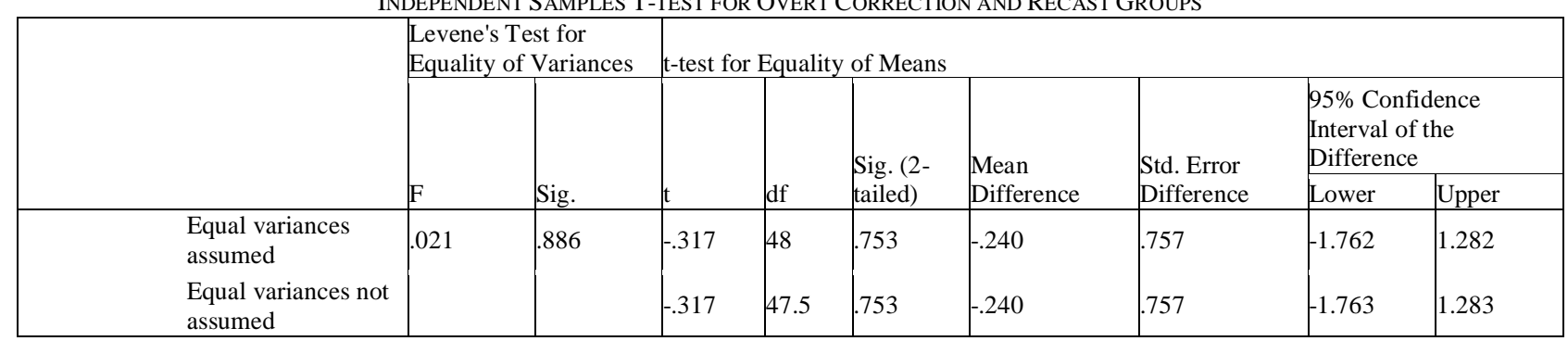


As Table VI indicates, the difference is not significant ( $\mathrm{t}=-.317, \mathrm{df}=48, \mathrm{p}>0.05)$. This means that the learners' grammar performance in overt correction and recast groups is not significantly different. In other words, while giving feedback helps the learners improve their grammar knowledge of English grammar, the type of feedback, overt correction or recast, cannot be a determining factor.

In the preset study, the first research question investigated whether recast helps Iranian EFL learners at intermediate level improve their grammar knowledge better than overt correction. The results of group statistics and independent samples $t$-test presented in Tables V and VI indicated that there was not a significant difference between the learners' grammar performance in overt correction and recast groups. Therefore, the first research hypothesis stating that recast does not help Iranian EFL learners at intermediate level improve their grammar knowledge better than overt correction is retained. Accordingly, the type of feedback is not a determining factor in the improvement of the students' grammar.

Regarding the second research question, the students' preferences to be notified through declarative or interrogative recasts, percentages were obtained. The results, presented in Table VII, indicate that 64 percent of Iranian EFL learners at intermediate level prefer their instructor use interrogative recasts as a feedback to their grammar performances compared with 36 percent who preferred declarative recasts.

TABLE VII.

THE PERCENTAGES OF RESPONDENTS

\begin{tabular}{|l|l|l|l|}
\hline & Frequency & Percent & Cumulative Percent \\
\hline Declarative & 9 & 36.0 & 36.0 \\
Interrogative & 16 & 64.0 & 100.0 \\
Total & 25 & 100.0 & \\
\hline
\end{tabular}

The second research question attempted to examine which methods of recast, declarative or interrogative, Iranian EFL learners at intermediate level prefer their instructors use as a feedback to their grammar performances. By referring to Table VII, one gets a quick impression about the percentage of the responses given by the learners in the recast group. 64 percent of the learners have a preference for interrogative recasts, whereas 26 percent of them preferred declarative recasts. Therefore, the second research hypothesis stating that Iranian EFL learners do not have any special preference for declarative or interrogative recasts is rejected.

The purpose of the current study was to discover which method of corrective feedback, overt correction or recast, is an effective means of improving the Iranian EFL learner's grammar knowledge at intermediate level. In addition, it was aimed at investigating which method of recast Iranian EFL students prefer to be used by their teachers, declarative or interrogative. The study findings are in agreement with the view of second language acquisition as 'cognitive skill' acquisition, according to which corrective feedback is an essential element in the complex process of language learning. On the other hand, the findings of this study are in contrast to nativism, according to which negative evidence does not cause any permanent change in the learners' grammar accuracy of target language, and if there is a change, it is a temporary one.

Furthermore, the study findings contradict Krashen's (1985) belief, according to which subconscious acquisition is dominant over conscious learning and corrective feedback does not play an important role in second language acquisition. The findings of the current study reveal that both overt correction and recast strategies have beneficial effects on learners' improvement in the process of English language learning and the learners' English grammar performance, in contrast to some previous research which reported negative or no effect for corrective feedback on learners' improvement (Krashen, 1985; Robb, Ross, \& Shortreed, 1986; Truscott, 1996; Fazio, 2001; Rahimi, 2009).

The findings of the study are consistent with Ashwell (2000) and Ferris and Roberts' (2001) claim that corrective feedback has some beneficial effects on learners' improvement in writing. Some other researchers believed that significantly those who received corrective feedback outperformed their counterparts who did not receive any feedback (Ferris \& Roberts, 2001; Leeman, 2003; Abadikhah \& Ashoori, 2012; Shirazi \& Sadighi, 2012).

They are also in contrast with the findings of Bitcher, Young, and Cameron (2005) as they did not find a positive effect for corrective feedback in general. Likewise, Ferris (2006) stated, "the research based on the questions of whether error feedback helps students to improve their accuracy in the short run or overtime is inadequate as to number of studies and inconsistent as to research design"(p. 81). The study results also contradict the findings of Rahimi's (2009) study, according to which there is no significant effect for the teacher's corrective feedback.

Language teaching methodologists in favor of overt correction suggested that it is more useful to learners since it lessens the perplexity that students may undergo when they do not succeed in identifying or recalling the meaning of teachers' error codes and fully inform them about their errors (Chandler, 2003; Ellis, Loewen, \& Erlam, 2006; Dabaghi \& Basturkmen, 2009). A number of researchers distinguished between the effects of different error treatment methods such as overt correction and recasts and found that overt correction group outperformed the recast group (Lyster, 2004; Rosa \& Leow, 2004; Ellis, 2006; Spada \& Tomita, 2010).

The studies supporting recasts suggested that this approach is better than overt correction since it gets learners involved in guided learning and problem solving. In addition, recasts promote the kind of reflection that leads to longterm acquisition and are student-centered, i.e. they are dependent upon what the student attempts to convey, and are inconspicuous, i.e. they indicate that an error occurs without leading to a breakdown in communication (Leeman, 2003; 
Long, 2006; Mackey \& Goo, 2007; Trofimovich, Ammar, \& Gatbonton, 2007; Perdomo, 2008; Lyster, Saito, \& Sato, 2013).

Although corrective feedback as an effective form of interaction has been validated by a large number of studies (Carrol \& Swain, 1993; Nagata, 1993; Muranoi, 2000; Carroll, 2001; Havranek \& Cesnik, 2001; Lyster, 2004), research showed that little or no significant difference can occur between implicit feedback (recasts) and overt corrective feedback (DeKeyser, 1993; Kim \& Mathes, 2001). These studies are in agreement with the findings of the present study in which no significant difference was found between the performances of both overt correction and recast groups.

In contrast to Sheen's (2006) view regarding the beneficial effect of declarative recasts which lead to a high level of repair compared with interrogative one, the findings of the current study support Mackey and Goo's (2007) study in which interrogative recasts were more accurately perceived than declarative recasts. The students' preference for interrogative recasts in the present study reveal that an interrogative recast is not ambiguous as corrective feedback and students are fully aware of the types of error corrections employed by their instructor, which is in contrast to Loewen and Philp's (2006) findings pertaining to the ambiguity of interrogative recasts.

\section{CONCLUSION}

This study was intended to examine which correction method, overt correction or recast, was more fruitful for Iranian EFL learners at intermediate level to show an improvement in their grammar performance. Moreover, it shed light on the students' preference to be notified through declarative or interrogative recasts. The results indicated that the Iranian EFL learners of English at intermediate level improved their grammar performance as a result of receiving corrective feedback. Therefore, corrective feedback provision resulted in an ascending pattern of improvement in learners' performance over time. These findings give emphasis to the significance of supplying corrective feedback in EFL settings where teachers' instruction and feedback are the most important ways through which learners can improve their language proficiency.

It should be notified that error making is an inevitable component of language learning, but one can reduce the number of these errors through providing the learners with corrective feedback. According to the findings of this study, it seems that learners give their undivided attention to the kind of corrective feedback provided by their teachers and use them to make positive changes in their performances. Briefly speaking, corrective feedback facilitates language learning process.

\section{REFERENCES}

[1] Abadikhah, S. \& A. Ashoori. (2012). The effect of written corrective feedback on EFL learners' performance after collaborative output. Journal of Language Teaching and Research 3.1, 118-125.

[2] Ashwell, T. (2000). Patterns of teacher response to student writing in a multiple-draft composition classroom: Is content feedback followed by form feedback the best method? Journal of Second Language Writing 9.3, 227-257.

[3] Bartram, M. \& R. Walton. (1994). Correction: A positive approach to language mistakes. Language Teaching Publications: England.

[4] Bitchener, J. (2008). Evidence in support of written corrective feedback. Journal of Second Language Writing 17.2, $102-118$.

[5] Bitchener, J. \& U. Knoch. (2009). The relative effectiveness of different types of direct written corrective feedback. System 37.2, 322-329.

[6] Bitchener, J., S. Young \& D. Cameron. (2005). The effect of different types of corrective feedback on ESL student writing. Journal of Second Language Writing 14.3, 191-205.

[7] Brown, H. D. (2007). Principles of language learning and teaching (5th edn.). White Plains, NY: Pearson Education.

[8] Carroll, S. (2001). Input and evidence: The raw material of second language acquisition. Amsterdam: John Benjamins.

[9] Carroll, S. \& M. Swain. (1993). Explicit and implicit negative feedback: An empirical study of the learning of linguistic generalizations. Studies in Second Language Acquisition 15.3, 357-386.

[10] Celce-Murcia, M. (ed.) (2001). Teaching English as a second or foreign language (3rd edn.). Boston: Heinle \& Heinle.

[11] Chandler, J. (2003). The efficacy of various kinds of error feedback for improvement in the accuracy and fluency of L2 student writing. Journal of Second Language Writing 12.3, 267-296.

[12] Chaudron, C. (1986). Teachers' priorities in correcting learners' errors in French immersion classes. In R. R. Day (ed.), Talking to learn: Conversation in second language acquisition. Rowley, MA: Newbury House, 64-84.

[13] Chaudron, C. (1988). Second language classrooms: Research on teaching and learning. Cambridge: Cambridge University Press.

[14] Dabaghi, A. \& H. Basturkmen. (2009). The effectiveness of implicit and explicit error correction on learners' performance. System 37.1, 82-98.

[15] Dekeyser, R. M. (1993). The effect of error correction on L2 grammar knowledge and oral proficiency. The modern language journal 77.4, 501-514.

[16] Dulay, H. C., M. K. Burt \& S. Krashen. (1982). Language two. Oxford: Oxford University Press.

[17] Edge, J. (1989). Mistakes and correction. New York: Longman.

[18] Ellis, R. (2006). Researching the effects of form-focussed instruction on L2 acquisition. AILA Review 19.1, 18-41.

[19] Ellis, R. (2009). A typology of written corrective feedback types. ELT Journal 63.2, 97-107.

[20] Ellis, R., S. Loewen \& R. Erlam (2006). Implicit and explicit corrective feedback and the acquisition of L2 grammar. Studies in Second Language Acquisition 28.2, 339-368. 
[21] Ellis, R., H. Rosszell \& H. Takashima. (1994). Down the garden path: Another look at negative feedback. JALT Journal 16, 9 24.

[22] Ellis, R. \& Y. Sheen. (2006). Re-examining the role of recasts in L2 acquisition. Studies in Second Language Acquisition 28.4, 575-600.

[23] Erlam, R. \& S. Loewen. (2010). Implicit and explicit recasts in L2 oral French interaction. Canadian Modern Language Review/La Revue canadienne des langues vivantes 66.6, 877-905.

[24] Farrar, M. J. (1990). Discourse and the acquisition of grammatical morphemes. Journal of Child Language 17.3, 607-624.

[25] Farrar, M. J. (1992). Negative evidence and grammatical morpheme acquisition. Developmental Psychology 28.1, 90-98.

[26] Fazio, L. (2001). The effect of corrections and commentaries on the journal writing accuracy of minority- and majoritylanguage students. Journal of Second Language Writing 10.4, 235-249.

[27] Ferris, D. R. (1999). The case for grammar correction in L2 writing classes: A response to Truscott (1996). Journal of Second Language Writing 8.1, 1-11.

[28] Ferris, D. R. (2006). Does error feedback help student writers? New evidence on the short- and long-term effects of written error correction. In K. Hyland \& F. Hyland (eds.), Perspectives on Response. Cambridge: Cambridge University Press.

[29] Ferris, D. R. \& B. Roberts (2001). Error feedback in L2 writing classes: How explicit does it need to be? Journal of Second Language Writing 10.3, 161-184.

[30] Han, Z. H. (2002). Rethinking the role of corrective feedback in communicative language teaching. RELC Journal 33.1, 1-33.

[31] Havranek, G. \& H. Cesnik (2001). Factors affecting the success of corrective feedback. EUROSLA Yearbook 1.1, 99-122.

[32] Herron, C. (1991). The garden path correction strategy in the foreign language classroom. The French Review 64.6, 966-977.

[33] Herron, C. \& M. Tomasello (1988). Learning grammatical structures in a foreign language: Modeling versus feedback. The French Review 61.6, 910-922.

[34] Hinkel, E. (ed.) (2011). Handbook of research in second language teaching and learning. (Vol. 2). New York: Routledge.

[35] Ishida, M. (2004). Effects of recasts on the acquisition of the aspectual form of -te $i$ (ru) by learners of Japanese as a foreign language. Language Learning 54.2, 311-394.

[36] Iwashita, N. (2003). Negative feedback and positive evidence in task-based interaction: Differential effects on L2 development. Studies in Second Language Acquisition 25.1, 1-36.

[37] Keh, C. L. (1990). Feedback in the writing process: A model and methods for implementation. ELT Journal 44.4, 294-304.

[38] Kim, H. R. \& G. Mathes (2001). Explicit vs. implicit corrective feedback. The Korea TESOL Journal 4.1, 57-72.

[39] Krashen, S. D. (1985). The input hypothesis: Issues and implications. New York: Longman.

[40] Leeman, J. (2003). Recasts and second language development: Beyond negative evidence. Studies in Second Language Acquisition 25.1, 37-63.

[41] Leow, R. P. (1998). Toward operationalizing the process of attention in SLA: Evidence for Tomlin and Villa's fine grained analysis of attention (1994). Applied Psycholinguistics 19, 133-159.

[42] Lightbown, P. M. \& N. Spada (1999). How languages are learned. Oxford: Oxford University Press.

[43] Loewen, S. \& J. Philp. (2006). Recasts in the adult English L2 classroom: Characteristics, explicitness, and effectiveness. The Modern Language Journal 90.4, 536-556.

[44] Long, M. (1996). The role of the linguistic environment in second language acquisition. In W. Ritchie \& T. Bhatia (eds.), Handbook of second language acquisition. San Diego, CA: Academic Press, 413-468.

[45] Long, M. (2006). Problems in SLA. Mahwah, NJ: Erlbaum.

[46] Long, M. \& P. Robinson (1998). Focus on form: Theory, research and practice. In C. Doughty \& J. Williams (eds.), Focus on form in classroom second language acquisition. New York: Cambridge University Press, 15-41.

[47] Lotfian, M. (2009). Progress toward ILI examinations: Pre 3-intermediate. Tehran: ILI Press.

[48] Lyster, R. (1998a). Negotiation of form, recasts, and explicit correction in relation to error types and learner repair in immersion classrooms. Language Learning 48.2, 183-218.

[49] Lyster, R. (1998b). Recasts, repetition and ambiguity in L2 classroom discourse. Studies in Second Language Acquisition 20.1, 51-81.

[50] Lyster, R. (2001). Negotiation of form, recasts and explicit correction in relation to error types and learner repair in immersion classrooms. Language Learning 51.1, 265-301.

[51] Lyster, R. (2004). Differential effects of prompts and recasts in form-focused instruction. Studies in Second Language Acquisition 26, 399-432.

[52] Lyster, R. \& L. Ranta. (1997). Corrective feedback and learner uptake: Negotiation of form in communicative classrooms. Studies in Second Language Acquisition 19.1, 37-66.

[53] Lyster, R., K. Saito \& M. Sato. (2013). Oral corrective feedback in second language classrooms. Language Teaching 46.1, 140.

[54] Mackey, A. \& J. Goo. (2007). Interaction research in SLA: A meta-analysis and research synthesis. In A. Mackey (ed.), Conversational interaction in second language acquisition: A collection of empirical studies. Oxford: Oxford University Press, 407-452.

[55] Mackey, A. \& R. Oliver. (2002). Interactional feedback and children's L2 development. System 30.4, $459-477$.

[56] McDonough, K. (2007). Interactional feedback and the emergence of simple past activity verbs in L2 English. In A. Mackey (ed.), Conversational interaction in second language acquisition: A collection of empirical studies. Oxford: Oxford University Press, 323-338.

[57] Muranoi, H. (2000). Focus on form through interaction enhancement: Integrating formal instruction into a communicative task in EFL classrooms. Language Learning 50.4, 617-673.

[58] Nagata, N. (1993). Intelligent computer feedback for second language instruction. The Modern Language Journal 77.3, 330339.

[59] Nassaji, H. \& M. Swain. (2000). A Vygotskyan perspective on corrective feedback in L2: The effect of random versus negotiated help in the learning of English articles. Language Awareness 9.1, 34-51. 
[60] Nicholas, H., P. M. Lightbown \& N. Spada. (2001). Recasts as feedback to language learners. Language Learning 51.4, 719758.

[61] Norris, J. \& L. Ortega. (2000). Effectiveness of L2 instruction: A research synthesis and quantitative meta-analysis. Language Learning 50.3, 417-528.

[62] Ortega, L. (2009). Understanding second language acquisition. London: Hodder Education.

[63] Panova, I. \& R. Lyster. (2002). Patterns of corrective feedback and uptake in an adult ESL classroom. TESOL Quarterly 36.4, 573-595.

[64] Perdomo, B. (2008). Effectiveness of recasts in the teaching of EFL. Asian EFL Journal 10.2, 155-166.

[65] Rahimi, M. (2009). The role of teacher's corrective feedback in improving Iranian EFL learners' writing accuracy over time: Is learner's mother tongue relevant? Reading and Writing 22.2, 219-243.

[66] Ranta, L. \& R. Lyster. (2007). A cognitive approach to improving immersion students' oral language abilities: The awarenesspractice-feedback sequence. In R. DeKeyser (ed.), Practice in a second language: Perspectives from applied linguistics and cognitive psychology. New York: Cambridge University Press, 141-160.

[67] R'ev'esz, A., R. Sachs \& A. Mackey. (2011). Task complexity, uptake of recasts, and L2 development. In P. Robinson (ed.), Second language task complexity: Researching the cognition hypothesis of language learning and performance. Amsterdam: John Benjamins, 203-235.

[68] Robb, T., S. Ross \& I. Shortreed. (1986). Salience of feedback on error and its effect on EFL writing quality. TESOL Quarterly 20.1, 83-95.

[69] Rosa, E. M. \& R. P. Leow. (2004). Awareness, different learning conditions, and second language development. Applied Psycholinguistics 25.2, 269-292.

[70] Sato, M. (2011). Constitution of form-orientation: Contributions of context and explicit knowledge to learning from recasts. Canadian Journal of Applied Linguistics/Revue canadienne de linguistique appliqué 14.1, 1-28.

[71] Schachter, J. (1991). Corrective feedback in historical perspective. Second Language Research 7.2, 89-102.

[72] Scott, V. M. (1989). An empirical study of explicit and implicit grammar teaching strategies in French. The Modern Language Journal 73.1, 14-22.

[73] Scott, V. M. (1990). Explicit and implicit grammar teaching strategies: New empirical data. The French Review 63.5, 779-789.

[74] Semke, H. (1984). The effect of the red pen. Foreign Language Annals 17.3, 195-202.

[75] Sheen, Y. (2004). Corrective feedback and learner uptake in communicative classrooms across instructional settings. Language Teaching Research 8.3, 263-300.

[76] Sheen, Y. (2006). Exploring the relationship between characteristics of recasts and learner uptake. Language Teaching Research 11.4, 361-392.

[77] Sheen, Y. (2007). The effect of corrective feedback, language aptitude and learner attitudes on the acquisition of English articles. In A. Mackey (ed.), Conversational interaction in second language acquisition. Oxford: Oxford University Press, 301322.

[78] Sheen, Y. (2008). Recasts, language anxiety, modified output, and L2 learning. Language Learning 58.4, 835-874.

[79] Sheen, Y. (2010). The role of oral and written corrective feedback on SLA. Studies in Second Language Acquisition 32.2, 169179.

[80] Shirazi, Z. R. H. \& F. Sadighi. (2012). Implicit versus explicit feedback in classroom: An experimental study. Journal of Language Teaching and Research 3.3, 439-445.

[81] Spada, N. \& Y. Tomita. (2010). Interactions between type of instruction and type of language feature: A meta-analysis. Language Learning 60.2, 263-308.

[82] Suzuki, M. (2005). Corrective feedback and learner uptake in adult ESL classrooms. http://journal.tclibrary.org/index.php/tesol/article/ viewPDFIntertitial/58/64 (accessed 28/6/2011).

[83] Tomasello, M. \& C. Herron (1989). Feedback for language transfer errors. Studies in Second Language Acquisition 11.4, 385395.

[84] Trofimovich, P., A. Ammar \& E. Gatbonton. (2007). How effective are recasts? The role of attention, memory, and analytic ability. In A. Macky (ed.), Conversational interaction in second language acquisition: A collection of empirical studies. Oxford: Oxford University Press, 171-195.

[85] Truscott, J. (1996). The case against grammar correction in L2 writing classes. Language Learning 46.2, 327-369.

[86] Yang, Y. \& R. Lyster. (2010). Effects of form-focused practice and feedback on Chinese EFL learners' acquisition of regular and irregular past tense forms. Studies in Second Language Acquisition 32, 235-263.

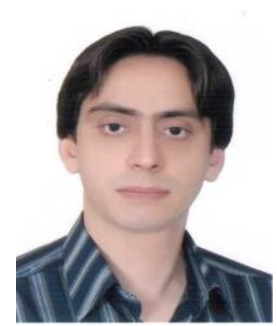

Seyyed Reza Mousavi Moghaddam (b. 1980, Yazd, Iran) has an associate degree in TEFL from Islamic Azad University of Rasht (2003-2005) and a B.A. in English language and literature from Islamic Azad University, South Tehran Branch (2006-2008). Currently, he is doing an M.A. in TEFL at Abadeh Branch, Islamic Azad University, Abadeh, Iran. He has been teaching at the Iran Language Institute, Yazd Branch since 2010. His research interests include corrective feedback, teaching, and psycholinguistics. 
Fatemeh Behjat holds a PhD in TEFL at English Department, Abadeh Branch, Islamic Azad University, Abadeh and also teaches at Islamic Azad University, Shiraz branch and at the Zand Institute of Higher Education, Shiraz, Iran. She has so far presented papers at international conferences in Iran and abroad, published books and a couple of articles in language journals. Her main area of interest is teaching and language acquisition. 